\title{
Are more environmentally sustainable diets with less meat and dairy nutritionally adequate?
}

\author{
S Marije Seves, Janneke Verkaik-Kloosterman, Sander Biesbroek and \\ Elisabeth HM Temme* \\ National Institute for Public Health and the Environment (RIVM), Postbus 1, 3720 BA Bilthoven, The Netherlands
}

Submitted 5 April 2016: Final revision received 20 January 2017: Accepted 4 April 2017: First published online 23 May 2017

\begin{abstract}
Objective: Our current food consumption patterns, and in particular our meat and dairy intakes, cause high environmental pressure. The present modelling study investigates the impact of diets with less or no meat and dairy foods on nutrient intakes and assesses nutritional adequacy by comparing these diets with dietary reference intakes.

Design: Environmental impact and nutrient intakes were assessed for the observed consumption pattern (reference) and two replacement scenarios. For the replacement scenarios, $30 \%$ or $100 \%$ of meat and dairy consumption (in grams) was replaced with plant-based alternatives and nutrient intakes, greenhouse gas emissions and land use were calculated.

Setting: The Netherlands.

Subjects: Dutch adults ( $n$ 2102) aged 19-69 years.

Results: Replacing $30 \%$ of meat and dairy with plant-based alternatives did not substantially alter percentages below the Estimated Average Requirement (EAR) for all studied nutrients. In the $100 \%$ replacement scenario, SFA intake decreased on average by $\sim 35 \%$ and $\mathrm{Na}$ intake by $\sim 8 \%$. Median $\mathrm{Ca}$ intakes were below the Adequate Intake. Estimated habitual fibre, Fe and vitamin D intakes were higher; however, non-haem Fe had lower bioavailability. For Zn, thiamin and vitamin $\mathrm{B}_{12}$, $10-31 \%$ and for vitamin A, $60 \%$ of adults had intakes below the EAR.

Conclusions: Diets with all meat and dairy replaced with plant-based foods lowered environmental impacts by $>40 \%$. Estimated intakes of $\mathrm{Zn}$, thiamin, vitamins $\mathrm{A}$ and $\mathrm{B}_{12}$, and probably $\mathrm{Ca}$, were below recommendations. Replacing $30 \%$ was beneficial for SFA, Na, fibre and vitamin D intakes, neutral for other nutrients, while reducing environmental impacts by $14 \%$.
\end{abstract}

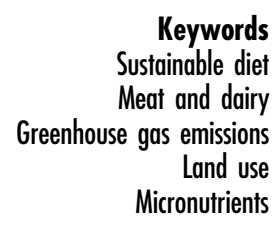

The limited resources on our planet and the world's growing population increase the need for sustainable food consumption $^{(1,2)}$. The food supply chain is a major cause of greenhouse gas (GHG) emissions ${ }^{(3)}$. The livestock sector accounts for $14.5 \%$ of human-induced GHG emissions and therefore plays an important role in climate change ${ }^{(4)}$. Meat and dairy products account for approximately $40 \%$ of all food-related emissions ${ }^{(5)}$. One of the goals for 2030 , set by the European Commission, is to reduce domestic EU emissions to at least $40 \%$ below 1990 levels $^{(6)}$.

Dietary changes could play an important role in reaching environmental goals. Diets with less meat and dairy could potentially lower diet-related GHG emissions by up to $50 \%$ in affluent countries via reductions in these products of $0-10 \%$ when balancing energy intake with energy requirements, $0-35 \%$ when eating a healthy diet and $25-55 \%$ for vegan diets ${ }^{(7)}$. More plant-based diets are also linked to health benefits, such as a lower risk of CHD and type 2 diabetes ${ }^{(8-10)}$. However, others have found that diets of high nutritional quality containing more plant foods had higher GHG emissions in self-selected French $\operatorname{diets}^{(11)}$. A healthier diet is thus not necessarily an environmentally friendlier diet. Although the evidence base for sustainable healthy diets is still under development, consensus among several health councils is that we should shift towards diets with fewer animal products and more plant-based foods ${ }^{(12,13)}$.

However, not many studies have evaluated the nutritional effects of shifting towards more sustainable diets on a population level or they included only a small range of nutrients. Reducing meat and dairy consumption may potentially pose nutritional challenges for some key nutrients, such as $\mathrm{Ca}, \mathrm{Fe}, \mathrm{Zn}$ and vitamin $\mathrm{B}_{12}{ }^{(5,14,15)}$. On the other hand, high intakes of meat and dairy products are associated with unfavourably high intakes of SFA and $\mathrm{Na}$, intakes of which currently exceed the recommendations for Dutch adults ${ }^{(16)}$. When adapting to more plantbased diets, attention to adequate thiamin, vitamin $\mathrm{B}_{12}$ 
and $\mathrm{Zn}$ intakes among young Dutch children is warranted ${ }^{(17)}$. Although it is expected that the effects for adults are similar, this has not yet been investigated.

The present paper examines the effects on nutrient intakes when shifting towards more plant-based diets to gain insight into possibly too low or too high intakes among certain subgroups of the Dutch adult population. Habitual intakes of energy, protein, SFA, fibre, $\mathrm{Na}, \mathrm{Ca}, \mathrm{Fe}, \mathrm{Zn}$, thiamin, riboflavin, vitamins $A, B_{12}$ and $D$ were evaluated for the current diet (reference), using data from the Dutch National Food Consumption Survey 2007-2010 (DNFCS), as well as for 'less meat and dairy' (30\%) and 'no meat and dairy' $(100 \%)$ scenarios. These intakes were compared with age- and gender-specific Dietary Reference Intakes (DRI).

\section{Methods}

\section{Food consumption data for the reference scenario}

Food consumption data for the observed consumption pattern (reference) were obtained from the DNFCS 2007$2010^{(16)}$. Food consumption data were based on two $24 \mathrm{~h}$ recalls that were conducted by dietitians on separate days about 4 weeks apart with the use of EPIC-Soft ${ }^{\circledR}$ program (currently known as GloboDiet) $^{(16)}$. Dietary supplement use was assessed on the recalled days and with an additional questionnaire. Food composition data were taken from the extended Dutch Food Composition Table (NEVO-table 2011/3.0) ${ }^{(18)}$. The study population is a representative sample of the Dutch population with respect to age, gender, region, degree of urbanisation and educational level. The overall response was 69\% $\left(n\right.$ 3819) ${ }^{(19)}$. For the present study, we included all men and women aged 19-69 years ( $n$ 2107). Those who consumed only meal replacers (for weight reduction; $n 1$ ) or those who were lactating and thus had different nutrient requirements $(n$ 4) were excluded. Calculations were based on 2102 individuals (1055 men and 1047 women).

\section{Replacement scenarios}

In the 'less meat and dairy' scenario, we replaced $30 \%$ of meat and dairy products (e.g. cheese and milk) consumed in the DNFCS with plant-based alternatives of the same quantity (in grams). The 'no meat and dairy' scenario replaced $100 \%$ of the consumed meat and dairy products with plant-based alternatives. Only foods that fully or predominantly consist of meat or dairy foods were replaced; for example, ready-to-eat porridge with milk was not replaced but a glass of milk was. The 'no meat and dairy' scenario can therefore still contain a small quantity of animal foods. Consumption of foods other than meat and dairy was assumed not to change. This also applied to fish and eggs.

To stay close to the current eating habits, replacement foods were foods with similar use in terms of consumption occasion. For instance, cheese consumed as a snack during the evening was replaced by a snack without meat or dairy and not by a sandwich filling. Moreover, replacement foods were of equal quantity as the original food consumed and had to be more environmentally sustainable (taking $\mathrm{CO}_{2}$ equivalents and land use as indicators) than meat and dairy (Table 1). Replacement foods currently available in the Netherlands were chosen from the Dutch Food Composition Database (NEVO-online 2013/4.0) ${ }^{(20)}$.

To model the replacement scenarios, a random number between 0 and 1 was allocated to each product consumed in the reference scenario and for each person on each observed day using the statistical software package SAS version 9.3. Milk products such as drinks, yoghurts and custards were replaced one-on-one by a soya-based drink, yoghurt or dessert. In the 'no meat and dairy' scenario, all dairy products were replaced and in the 'less meat and dairy' scenario only the dairy products with a number in the range $0 \cdot 000-0 \cdot 300$ were replaced with a dairy substitute. For meat consumed at dinner, and meat and cheese as sandwich filling or snack, various substitutes were available. For replacing meat at dinner, three categories were

Table 1 Methods for assignment of replacement foods

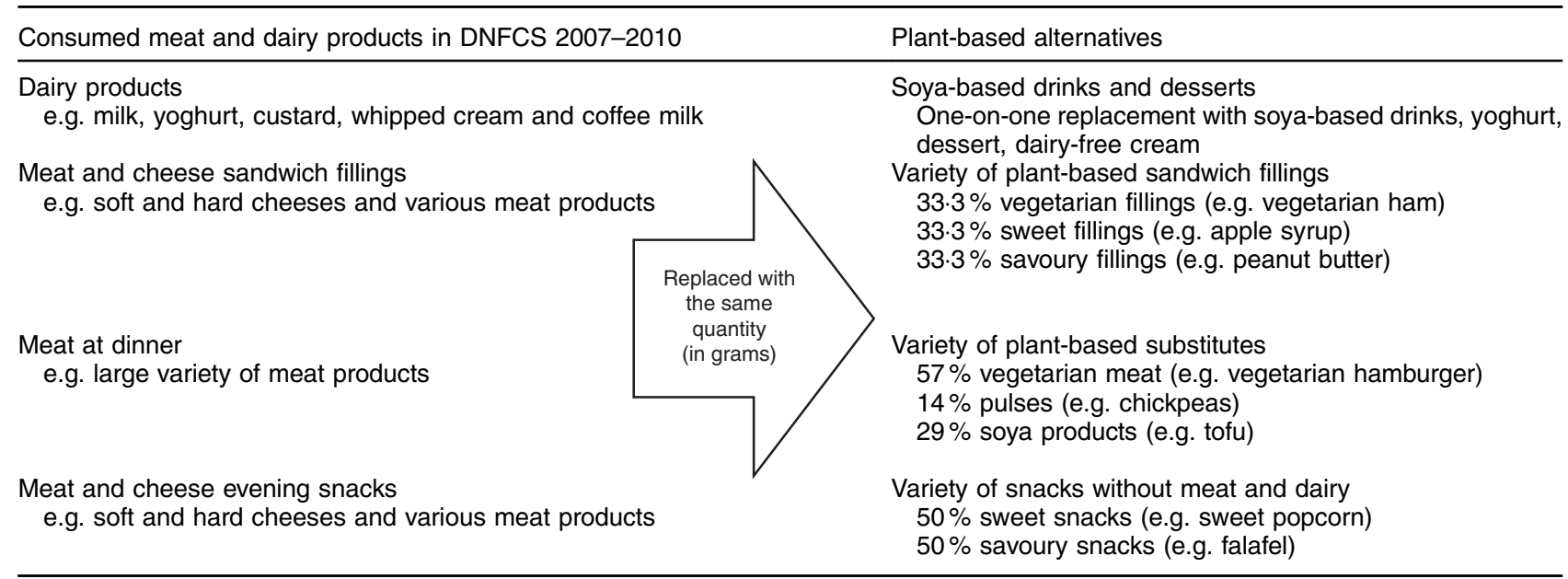

DNFCS, Dutch National Food Consumption Survey. 
used: vegetarian meat, pulses and soya products. These are also considered suitable meat substitutes according to the Netherlands Nutrition Centre ${ }^{(21)}$. In the 'no meat and dairy' scenario, $57 \%$ (four times per week) of meat replacement was allocated to vegetarian meat replacers such as vegetarian burgers, 29\% (twice per week) to soya products and $14 \%$ (once per week) to pulses. In the 'no meat and dairy' scenario, vegetarian meat was chosen as a substitute if the allocated number fell within the range 0.000-0.570. If the number fell in the range $0.571-0.710$ pulses were chosen, and in the range $0 \cdot 711-1.000$ soya products were selected. In the 'less meat and dairy' scenario, these ranges were $0 \cdot 000-0 \cdot 171,0 \cdot 172-0 \cdot 213$ and $0 \cdot 214-0 \cdot 300$, respectively, since only $30 \%$ of the consumed products were replaced. For sandwich filling, three categories were determined: vegetarian fillings (e.g. vegetarian pâté), sweet fillings (e.g. honey and jam) and savoury fillings (peanut butter and sandwich spread). All categories had a one-third chance of being chosen and consisted of a variety of substitutes. Meat and cheese consumed during the evening were considered to be a snack and therefore replaced with a plant-based snack. These were savoury snacks (e.g. falafel) or sweet snacks (e.g. sweet popcorn) and had a probability of 0.5 in the 'no meat and dairy' scenario and of 0.15 in the 'less meat and dairy' scenario. In case a subdivision per category was made, the probability for each substitute was the same. For example, the probability of selecting honey or jam was identical. The number allocation was repeated ten times for each scenario. Since the differences in mean nutrient intakes between these replicates was very small $(\mathrm{CV}<1 \%)$, one allocation was randomly chosen to represent that scenario.

\section{Habitual intake distributions}

The main interest is in the long-term nutrient intake, also called the habitual or usual intake; therefore a statistical model was applied to two $24 \mathrm{~h}$ recalls per person, which accounted for the intra-individual variation (day-to-day variation). With SPADE (Statistical Program to Assess Dietary Exposure, version 2.29.01), habitual nutrient intake was modelled as a function of age for men and women separately ${ }^{(22)}$. Habitual intake distributions for energy and macronutrients were estimated using the onepart model (for components consumed on a daily basis by all subjects). Habitual distributions for vitamins and minerals from food sources and dietary supplements combined were estimated with a three-part model, as described by Verkaik-Kloosterman et al. ${ }^{(23)}$. In this model, the habitual intake from food sources was estimated separately for users and non-users of dietary supplements to retain potential differences in dietary intake between these groups. For the users of dietary supplements, also the habitual intake from supplements was estimated. The habitual intakes from food sources and dietary supplements were combined for users of dietary supplements to get the total habitual intake. Combining the habitual intake distributions of non-users and users of dietary supplements provides the habitual intake distribution for the total population. Individuals were considered as potential supplement users based on the dietary supplement questionnaire and/or supplement use during the two recalled days. Individuals were assigned as potential supplement users separately for each nutrient. Supplement use in the replacement scenarios was assumed to be equal to the reference scenario.

\section{Dietary Reference Intakes}

The population's habitual nutrient intake distributions for the reference and replacement scenarios were compared with the DRI. In order to evaluate whether intakes are adequate on a population level, the Estimated Average Requirement (EAR) cut-point method was used as described by Carriquiry ${ }^{(24)}$. To exclude modelling uncertainties, the intake was considered adequate when the 95\% confidence limit of the proportion below the EAR included $2.5 \%$ or less ${ }^{(25)}$. For fibre, Ca, thiamin (51-69 years) and vitamin D, an Adequate Intake (AI) was available, which allows for only a qualitative evaluation of the intake ${ }^{(26)}$. In some cases, also a Tolerable Upper Intake Level (UL) was available, which is the maximum level of daily intake likely to pose no risk or adverse effects ${ }^{(27)}$. The proportion of adults with intakes below the EAR and/or above the UL was calculated. The recommendations were obtained from dietary reference values of the Health Council of the Netherlands (for energy, protein, $\mathrm{SFA}^{(28)}$, fibre ${ }^{(29)}, \mathrm{Ca}$, thiamin and riboflavin ${ }^{(30)}$, vitamin $\mathrm{A}^{(31)}$, vitamin $\mathrm{B}_{12}{ }^{(32)}$ and vitamin $\mathrm{D}^{(33)}$ ), the Nordic Nutrition Recommendations (for $\mathrm{Zn}$ and $\mathrm{Fe}^{(12)}$ ), and the European Food Safety Authority (for the UL of $\mathrm{Zn}$ and vitamins A and $\mathrm{D}^{(34,35)}$ ). Since the Dutch Food Composition Table ${ }^{(18)}$ did not distinguish between free and intrinsic sugars, the change in mono- and disaccharide content of the scenarios was used as a proxy for free sugar intake, but could therefore not be compared with the DRI.

\section{Environmental impact of foods}

Two indicators were used for the evaluation of environmental impacts: GHG emission ( $\mathrm{kg} \mathrm{CO}$-eq/d) and land use $\left(\mathrm{m}^{2} \times\right.$ year/d). GHG emission is an indicator for global warming potential ${ }^{(2)}$ and in the present study covers not only $\mathrm{CO}_{2}$ emissions through the use of fossil fuels, but also $\mathrm{CH}_{4}$ and $\mathrm{N}_{2} \mathrm{O}$ emissions expressed as $\mathrm{CO}_{2}$ equivalents $\left(\mathrm{CO}_{2}\right.$-eq). Land use covers the surface needed for the production of food during a certain period of time ${ }^{(36)}$. The environmental impacts were estimated via life cycle assessments by Blonk Consultants (data set version 2012). In life cycle assessment, the total amount of emissions and resources used are calculated throughout the whole life cycle of a product (i.e. cradle to grave assessment). Environmental data were accessible for 254 frequently consumed food items covering about $80 \%$ of the total food weight (in $\mathrm{g} / \mathrm{d}$ ) consumed in the DNFCS. Extrapolations were made to $>1300$ other food codes by an experienced 
dietitian, based on similarities in type of food, production system and ingredient composition. Transport from grocery store to home was not included due to large variations. Besides, this transport can be considered the same for different products ${ }^{(36)}$. The life cycle assessment data were combined with the food consumption data to calculate daily GHG emissions and land use for each of our subjects.

\section{Statistical analysis}

Habitual nutrient intakes and environmental impact distributions were modelled using SPADE. Mean habitual nutrient intakes (with 95\% CI) are presented for each nutrient, or as a median for nutrients when compared with an AI. All analyses on habitual nutrient intakes and environmental indicators were performed for men and women separately. The results are presented for the age groups 19-30, 31-50 and 51-69 years. A weighting factor was included to account for small deviances in sociodemographic characteristics, days of the week and season of data collection, to make the results representative for the Dutch adult population, for every day of the week and every season. The $95 \%$ CI were computed using the bootstrap method with 200 iterations. Significant differences between scenarios were evaluated by nonoverlapping $95 \%$ CI. In general, nutrient distributions tend to be non-symmetrical. Therefore, plots were used to visually check whether the confidence bounds of the distributions overlapped over the whole range of percentiles. Although the mean point estimates may be significantly different, there might still be some overlap at the highest and lowest percentiles.

\section{Results}

\section{Nutrient composition and environmental impact per food item}

Meat causes higher GHG emissions and land use than meat alternatives (Table 2). However, the variation between different kinds of meat products was large, with for example lower impacts for chicken $\left(4.6 \mathrm{CO}_{2}-\mathrm{eq} / \mathrm{kg}\right)$ than for beef $\left(19.6 \mathrm{CO}_{2}-\mathrm{eq} / \mathrm{kg}\right)$. GHG emissions of meat replacers ranged from 1.5 to $2 \cdot 2 \mathrm{CO}_{2}$-eq $/ \mathrm{kg}$. Average land use and GHG emissions for $1 \mathrm{~kg}$ of cow's milk were almost twice as high as for $1 \mathrm{~kg}$ of soya drink (Table 3).

Energy content varied between the various products, but was more or less similar for meat/dairy and their alternatives (Tables 2 and 3). Based on the DNFCS 20072010, meat and dairy products were consumed much more frequently than vegetarian meat substitutes and soya products. Vegetarian meat substitutes contained less vitamins $\mathrm{A}$ and $\mathrm{D}$ and $\mathrm{Zn}$ than meat. Pulses do not contain vitamin $B_{12}$ and have lower protein content than meat. On the other hand, fibre content was higher in vegetarian meat and pulses than in meat products and cheese. Na content of commercially available meat replacements was relatively high compared with pulses and soya products.
Most of the commercially available meat replacements are enriched with $\mathrm{Fe}$ and vitamin $\mathrm{B}_{12}{ }^{(37)}$, and dairy replacements may be enriched with $\mathrm{Ca}$, riboflavin and vitamins $\mathrm{B}_{12}$ and $\mathrm{D}^{(38)}$. Soya drinks contain more vitamin $\mathrm{D}$ than cow's milk. Sugar content of dairy replacements was somewhat higher in some of the variants. In our population, cheese was the most consumed sandwich filling as well as the most consumed animal-based snack after dinner. Furthermore, plant-based sandwich fillings such as peanut butter and sweet snacks such as Dutch spiced bread were frequently consumed in the reference scenario. Some sandwich fillings such as chocolate sprinkles and apple syrup contain (non-haem) Fe, but also have high sugar contents.

\section{Environmental impact of a day's consumption}

In the reference scenario, the average habitual GHG emission was $4.3 \mathrm{~kg} \mathrm{CO}_{2}$-eq/person per d; the 5 th-95th percentile ranged from 3.2 to $6.8 \mathrm{~kg} \mathrm{CO} \mathrm{CO}_{2}$-eq/d for men and from 2.5 to $5 \cdot 1 \mathrm{~kg} \mathrm{CO}$-eq/d for women. Habitual land use was $4.4 \mathrm{~m}^{2} /$ person per d. Men's daily diet generally had a higher environmental impact than women's diet in all scenarios. In the 'less meat and dairy' scenario, GHG emissions and land use were both reduced by on average $14 \%$ compared with the reference scenario. In the 'no meat and dairy' scenario, GHG emissions and land use were reduced by $47 \%$ and $41 \%$, on average, respectively. The reduction potential was more or less similar for men and women.

\section{Nutritional value of a day's consumption}

The 'less meat and dairy' scenario showed the same trend for the shift in nutrient intakes as the 'no meat and dairy' scenario, but with a smaller deviation from the reference (Fig. 1).

In general, macro- and micronutrient intakes were higher for men than for women. The average habitual energy intake for men in the reference scenario was approximately $11.0 \mathrm{MJ} / \mathrm{d}$ and for women this was $8.4 \mathrm{MJ} / \mathrm{d}$, depending on the age category (Table 4). The replacement scenarios did not alter energy intake significantly. The habitual daily protein intake in the reference scenario was $98 \mathrm{~g}$ for men and $76 \mathrm{~g}$ for women. Even though protein intake decreased to $77 \mathrm{~g} / \mathrm{d}$ for men and $60 \mathrm{~g} / \mathrm{d}$ for women in the 'no meat and dairy' scenario, the percentage below the EAR remained low (3\% below the corresponding EAR for women and $1 \%$ for men). In the reference scenario, almost all Dutch adults had a habitual SFA intake above the UL of $10 \mathrm{E} \%$ (percentage of daily energy intake). In the 'no meat and dairy' scenario, SFA intake decreased significantly by $35-36 \%$, which resulted in a lower proportion of the population with too high intakes (19\% above the UL for men compared with $97 \%$ in the reference scenario). The mean habitual mono- and disaccharide intakes (as a proxy for sugar) increased by $6 \%$ and $16-18 \%$ in the 'less meat and dairy' and 'no meat 


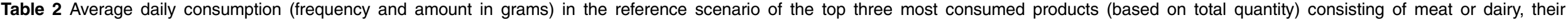
corresponding environmental impact per kilogram of product and their corresponding nutritional composition per $100 \mathrm{~g}$ of product

\begin{tabular}{|c|c|c|c|c|c|c|c|c|c|c|c|c|c|c|c|c|c|c|}
\hline \multirow[b]{2}{*}{ Product } & \multicolumn{2}{|c|}{$\begin{array}{l}\text { Consumption in } \\
\text { reference scenario }\end{array}$} & \multicolumn{2}{|c|}{$\begin{array}{l}\text { Environmental } \\
\text { impacts } / \mathrm{kg}\end{array}$} & \multicolumn{14}{|c|}{ Nutritional composition/100 g product } \\
\hline & $\begin{array}{l}\text { Frequency of } \\
\text { consumption* }\end{array}$ & $\begin{array}{l}\text { Average } \\
\text { portion } \\
\text { size }(\mathrm{g})\end{array}$ & $\begin{array}{c}\text { GHG } \\
\text { emissions } \\
\text { (kg CO} 2^{-} \\
\text {eq) }\end{array}$ & $\begin{array}{l}\text { Land } \\
\text { use }\left(\mathrm{m}^{2}\right. \\
\times \text { year })\end{array}$ & $\begin{array}{l}\text { Energy } \\
(\mathrm{kJ})\end{array}$ & $\begin{array}{l}\text { Protein } \\
\text { (g) }\end{array}$ & $\begin{array}{l}\text { SFA } \\
(g)\end{array}$ & $\begin{array}{l}\text { Monodisacc. } \\
\text { (g) }\end{array}$ & $\begin{array}{l}\text { Fibre } \\
(\mathrm{g})\end{array}$ & $\begin{array}{c}\mathrm{Na} \\
(\mathrm{mg})\end{array}$ & $\begin{array}{c}\mathrm{Ca} \\
(\mathrm{mg})\end{array}$ & $\mathrm{Fe}(\mathrm{mg})$ & $\begin{array}{l}\text { Zinc } \\
(\mathrm{mg})\end{array}$ & $\begin{array}{c}\text { Vitamin } \\
\text { A ( } \mu g \\
\text { RAE) }\end{array}$ & $\begin{array}{c}\text { Thiamin } \\
(\mathrm{mg})\end{array}$ & $\begin{array}{l}\text { Riboflavin } \\
\quad(\mathrm{mg})\end{array}$ & $\begin{array}{l}\text { Vitamin } \\
\mathrm{B}_{12}(\mu \mathrm{g})\end{array}$ & $\begin{array}{l}\text { Vitamin } \\
D(\mu \mathrm{g})\end{array}$ \\
\hline \multicolumn{19}{|l|}{ Meat } \\
\hline Chicken fillet & 226 & 90 & 4.6 & 6.9 & 464 & 23.3 & 0.5 & 0.0 & 0.0 & 53 & 6 & 0.6 & 0.65 & 30 & 0.08 & 0.03 & 0.20 & $2 \cdot 5$ \\
\hline Minced meat, beef/pork & 181 & 82 & 15.5 & $17 \cdot 8$ & 969 & $19 \cdot 2$ & 6.9 & 0.3 & 0.3 & 177 & 9 & 1.3 & 3.22 & 16 & 0.27 & 0.13 & 1.25 & 0.3 \\
\hline Minced meat, beef & 139 & 85 & $19 \cdot 6$ & 23.0 & 937 & 18.9 & $7 \cdot 0$ & 0.2 & 0.3 & 110 & 8 & 2.0 & 4.33 & 18 & 0.03 & 0.13 & 1.90 & 0.1 \\
\hline \multicolumn{19}{|l|}{ Dairy } \\
\hline Milk, semi-skimmed & 1360 & 186 & 1.3 & 0.8 & 192 & 3.4 & 1.0 & 4.6 & 0.0 & 39 & 122 & 0.0 & 0.41 & 16 & 0.03 & 0.18 & 0.45 & 0.0 \\
\hline Yoghurt, low fat & 262 & 197 & 1.2 & 0.8 & 161 & 4.2 & 0.2 & 4.1 & 0.0 & 42 & 150 & 0.0 & 0.61 & 2 & 0.02 & 0.17 & 0.27 & 0.0 \\
\hline Buttermilk & 195 & 265 & 1.5 & 1.0 & 131 & 3.0 & 0.2 & 3.6 & 0.0 & 37 & 108 & 0.0 & 0.41 & 2 & 0.02 & 0.15 & 0.13 & 0.0 \\
\hline \multicolumn{19}{|l|}{ Sandwich fillingt } \\
\hline Cheese, Gouda $48+$ & 1269 & 33 & $12 \cdot 3$ & $7 \cdot 6$ & 1526 & $22 \cdot 8$ & $19 \cdot 8$ & 0.0 & 0.0 & 760 & 815 & 0.2 & 3.47 & 332 & 0.01 & 0.29 & 1.97 & 0.2 \\
\hline Ham, shoulder, medium & 256 & 28 & $5 \cdot 4$ & $6 \cdot 1$ & 556 & $16 \cdot 4$ & $2 \cdot 1$ & 0.6 & 0.4 & 1120 & 9 & 0.8 & $2 \cdot 20$ & 1 & 0.41 & 0.17 & 0.44 & 0.0 \\
\hline $\begin{array}{l}\text { Cheese, } 30+ \\
\text { Snacks during evening } \ddagger\end{array}$ & 224 & 29 & $12 \cdot 3$ & 7.6 & 1205 & $30 \cdot 4$ & $12 \cdot 1$ & 0.0 & 0.0 & 735 & 1045 & 0.2 & 4.71 & 178 & 0.02 & 0.33 & 1.57 & 0.2 \\
\hline Cheese, Gouda 48+ & 107 & 33 & $12 \cdot 3$ & $7 \cdot 6$ & 1526 & $22 \cdot 8$ & $19 \cdot 8$ & 0.0 & 0.0 & 760 & 815 & 0.2 & 3.47 & 332 & 0.01 & 0.29 & 1.97 & 0.2 \\
\hline Croquette, meat ragoût & 23 & 46 & 11.9 & $11 \cdot 1$ & 813 & 7.5 & 4.6 & 1.5 & 1.3 & 521 & 21 & $1 \cdot 7$ & 1.40 & 3 & 0.04 & 0.01 & 0.51 & 0.7 \\
\hline $\begin{array}{l}\text { Frikandel (deep-fried } \\
\text { sausage) }\end{array}$ & 11 & 74 & 5.9 & $7 \cdot 3$ & 1006 & 14.5 & $6 \cdot 1$ & 1.5 & $1 \cdot 1$ & 853 & 86 & $2 \cdot 0$ & 1.00 & 27 & 0.07 & 0.10 & - & 0.6 \\
\hline
\end{tabular}

GHG, greenhouse gas; $\mathrm{CO}_{2}$-eq, $\mathrm{CO}_{2}$ equivalents; monodisacc., mono- and disaccharides; RAE, retinol activity equivalents. - means not available in NEVO-online (2013)

*Based on the number of consumers of the product in the Dutch National Food Consumption Survey 2007-2010 ( $n$ 2102).

†Most consumed meat and cheese as sandwich filling.

¥Most consumed snacks during the evening. 


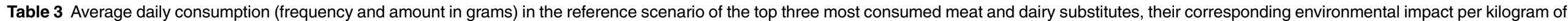
product and their corresponding nutritional composition per $100 \mathrm{~g}$ of product

\begin{tabular}{|c|c|c|c|c|c|c|c|c|c|c|c|c|c|c|c|c|c|c|}
\hline \multirow[b]{2}{*}{ Product } & \multicolumn{2}{|c|}{$\begin{array}{l}\text { Consumption in reference } \\
\text { scenario }\end{array}$} & \multicolumn{2}{|c|}{$\begin{array}{l}\text { Environmental } \\
\text { impacts } / \mathrm{kg}\end{array}$} & \multicolumn{14}{|c|}{ Nutritional composition/100 g product } \\
\hline & $\begin{array}{l}\text { Frequency of } \\
\text { consumption }^{*}\end{array}$ & $\begin{array}{l}\text { Average } \\
\text { portion } \\
\text { size }(\mathrm{g})\end{array}$ & $\begin{array}{l}\text { GHG } \\
\text { emissions } \\
\text { (kg CO } \mathrm{CO}_{2^{-}} \\
\text {eq) }\end{array}$ & $\begin{array}{l}\text { Land use } \\
\left(\mathrm{m}^{2} \times\right. \\
\text { year })\end{array}$ & $\begin{array}{c}\text { Energy } \\
\text { (kJ) }\end{array}$ & $\begin{array}{l}\text { Protein } \\
\text { (g) }\end{array}$ & $\begin{array}{l}\text { SFA } \\
(\mathrm{g})\end{array}$ & $\begin{array}{c}\text { Monodisacc. } \\
(\mathrm{g})\end{array}$ & $\begin{array}{l}\text { Fibre } \\
(\mathrm{g})\end{array}$ & $\begin{array}{l}\mathrm{Na} \\
(\mathrm{mg})\end{array}$ & $\begin{array}{c}\mathrm{Ca} \\
(\mathrm{mg})\end{array}$ & $\begin{array}{l}\mathrm{Fe} \\
(\mathrm{mg})\end{array}$ & $\begin{array}{l}\mathrm{Zn} \\
(\mathrm{mg})\end{array}$ & $\begin{array}{l}\text { Vitamin A } \\
\text { ( } \mu \text { g RAE) }\end{array}$ & $\begin{array}{l}\text { Thiamin } \\
(\mathrm{mg})\end{array}$ & $\begin{array}{l}\text { Riboflavin } \\
\text { (mg) }\end{array}$ & $\begin{array}{l}\text { Vitamin } \\
B_{12}(\mu \mathrm{g})\end{array}$ & $\underset{(\mu \mathrm{g})}{\text { Vitamin } D}$ \\
\hline \multicolumn{19}{|l|}{ Meat substitutes } \\
\hline \multicolumn{19}{|l|}{ Vegetarian meat } \\
\hline Vegetable burger & 4 & 88 & 1.5 & 1.7 & 904 & 11.6 & 1.2 & 4.4 & 3.7 & 634 & 0 & $2 \cdot 3 \dagger$ & - & 0 & - & 0.14 & $0.25 \dagger$ & 0.0 \\
\hline Mincemeat balls (veg) & 3 & 83 & $2 \cdot 2$ & $2 \cdot 7$ & 741 & 17.0 & 1.0 & 1.3 & 3 & 695 & 75 & $2.1 \dagger$ & 0.10 & 0 & 0.10 & 0.14 & $0.15 \dagger$ & 0.0 \\
\hline \multicolumn{19}{|l|}{ Pulses } \\
\hline Brown beans & 28 & 126 & 1.3 & 1.2 & 458 & 6.7 & 0.1 & 1.6 & $8 \cdot 1$ & 230 & 39 & 1.5 & 0.56 & 0 & 0.06 & 0.04 & 0.00 & 0.0 \\
\hline Beans in tomato sauce & 13 & 138 & 1.3 & 1.0 & 385 & 5.6 & 0.1 & 4.1 & $5 \cdot 2$ & 360 & 58 & 1.8 & 0.61 & 6 & 0.06 & 0.04 & 0.00 & 0.0 \\
\hline \multirow{2}{*}{\multicolumn{19}{|c|}{ Soya products }} \\
\hline & & & & & & & & & & & & & & & & & & \\
\hline Tahoe/tofu & 5 & 69 & 1.6 & $2 \cdot 2$ & 472 & 11.6 & 1.0 & 1.0 & 0.3 & 6 & 188 & 2.2 & $1 \cdot 10$ & 19 & 0.07 & 0.02 & 0.00 & 0.0 \\
\hline Tempe & 1 & 68 & 1.6 & $2 \cdot 2$ & 624 & 12.2 & 1.1 & $5 \cdot 6$ & $5 \cdot 6$ & 8 & 91 & 2.0 & 1.30 & 2 & 0.05 & 0.25 & 0.00 & 0.0 \\
\hline \multicolumn{19}{|l|}{ Dairy substitutes } \\
\hline Soya drink, light & 14 & 194 & 0.4 & 0.5 & 119 & $2 \cdot 1$ & 0.2 & 1.7 & $1.0 \dagger$ & 40 & $120 \dagger$ & 0.2 & 0.15 & 0 & 0.00 & $0.21 \dagger$ & $0.38 \dagger$ & $0.8 \dagger$ \\
\hline Breakfast drink, fruit-based & 11 & 244 & 0.6 & 0.1 & 219 & 0.4 & 0.0 & $10 \cdot 4$ & 0.7 & 2 & 6 & 0.3 & - & 0 & $0.20 \dagger$ & 0.01 & 0.00 & 0.0 \\
\hline Soya drink, several flavours & 8 & 272 & 0.4 & 0.5 & 251 & 2.9 & 0.3 & 7.5 & 0.6 & 68 & $120 \dagger$ & 0.3 & 0.23 & 1 & 0.02 & $0.21 \dagger$ & $0.38 \dagger$ & $0.8 \dagger$ \\
\hline \multicolumn{19}{|l|}{ Plant-based sandwich fillings } \\
\hline Vegetable paste & 3 & 30 & $1 \cdot 3$ & $2 \cdot 8$ & 915 & 7.5 & $2 \cdot 7$ & $7 \cdot 6$ & - & 461 & - & 0.0 & - & - & 1.00 & 2.00 & 0.00 & - \\
\hline Luncheon meat (veg) & 3 & 17 & 1.5 & 1.7 & 1354 & $15 \cdot 0$ & $3 \cdot 2$ & 0.0 & 1.0 & 815 & 1 & $2.1 \dagger$ & 0.01 & 0 & 0.08 & 0.09 & $0.15 \dagger$ & 0.0 \\
\hline Pâté (veg) & 2 & 40 & 1.5 & 1.7 & 1274 & 7.8 & $3 \cdot 2$ & 1.4 & 1.9 & 700 & 39 & $2 \cdot 1 \dagger$ & 0.04 & 0 & 0.06 & 0.08 & $0.15 \dagger$ & 0.0 \\
\hline \multicolumn{19}{|l|}{ Sweet fillings } \\
\hline Jam & 265 & 28 & $2 \cdot 3$ & 0.6 & 1044 & 0.3 & 0.0 & $52 \cdot 3$ & 0.9 & 10 & 8 & 0.4 & 0.04 & 7 & 0.01 & 0.01 & 0.00 & 0.0 \\
\hline Chocolate sprinkles, dark & 183 & 15 & $2 \cdot 2$ & 1.2 & 1887 & 5.8 & 9.0 & 60.5 & 6.6 & 27 & 36 & 8.1 & 1.27 & 4 & 0.02 & 0.05 & 0.21 & 0.0 \\
\hline Apple syrup & 118 & 25 & 1.3 & 0.7 & 1001 & 1.9 & 0.0 & 55.1 & 4.0 & 36 & 30 & 11.3 & 0.79 & 0 & 0.04 & 0.10 & 0.00 & 0.0 \\
\hline \multicolumn{19}{|l|}{ Savoury fillings } \\
\hline Peanut butter & 198 & 28 & $1 \cdot 7$ & $5 \cdot 1$ & 2792 & 22.4 & 8.3 & 4.4 & 8.0 & 250 & 50 & 1.4 & 2.30 & 0 & 0.10 & 0.10 & 0.00 & 0.0 \\
\hline $\begin{array}{l}\text { Sandwich spread, } \\
\text { original }\end{array}$ & 40 & 28 & 0.7 & 1.5 & 975 & 1.6 & 1.2 & 14.0 & 0.8 & 532 & 56 & $2 \cdot 0$ & - & 44 & 0.02 & 0.02 & - & 0.1 \\
\hline \multicolumn{19}{|l|}{ Snack substitutes } \\
\hline \multicolumn{19}{|l|}{ Sweet snacks } \\
\hline Dutch spiced bread & 265 & 28 & $1 \cdot 2$ & $2 \cdot 0$ & 1325 & 3.0 & 0.2 & 37.4 & 3.5 & 238 & 17 & 0.7 & 0.65 & 0 & 0.02 & 0.03 & 0.00 & 0.1 \\
\hline Popcorn (sweet) & 3 & 25 & 0.9 & 3.7 & 1649 & 9.9 & 0.8 & 24.0 & 3.8 & 2 & 8 & 0.9 & 0.08 & 4 & 0.30 & 0.09 & 0.00 & 0.0 \\
\hline Dried fruits & 1 & 14 & 0.5 & 0.6 & 1128 & 2.0 & 0.0 & $50 \cdot 8$ & $12 \cdot 4$ & 14 & 68 & 1.8 & 0.43 & 56 & 0.04 & 0.09 & 0.00 & 0.0 \\
\hline \multicolumn{19}{|l|}{ Savoury snacks } \\
\hline Sausage (veg) & 2 & 75 & 1.5 & 1.7 & 1074 & 13.3 & $2 \cdot 4$ & 1.8 & 0.6 & 773 & 20 & $2 \cdot 1 \dagger$ & - & 0 & - & 0.14 & $0.15 \dagger$ & 0.0 \\
\hline Falafel & 2 & 47 & 1.3 & 2.8 & 893 & 7.0 & 1.4 & 3.0 & 5.5 & 475 & 27 & $2.1 \dagger$ & 0.85 & 1 & 0.07 & 0.03 & $0.15 \dagger$ & 0.0 \\
\hline Nuggets (veg) & 0 & 0 & 1.5 & 1.7 & 1064 & 15.0 & 2.3 & 1.0 & 2.0 & 600 & 67 & $2.1 \dagger$ & 0.10 & 0 & 0.11 & 0.14 & $0.15 \dagger$ & 0.0 \\
\hline
\end{tabular}

GHG, greenhouse gas; $\mathrm{CO}_{2}$-eq, $\mathrm{CO}_{2}$ equivalents; monodisacc, mono- and disaccharides; $\mathrm{RAE}$, retinol activity equivalents; veg, vegetarian.

*Based on the number of consumers of the product in the Dutch National Food Consumption Survey 2007-2010 ( $n$ 2102).

†Fortified with vitamins and/or minerals. 
and dairy' scenario, respectively, compared with the reference. Mean mono- and disaccharide intakes varied around $23 \mathrm{E} \%$ for men and $26 \mathrm{E} \%$ for women in the 'no meat and dairy' scenario compared with $20 \mathrm{E} \%$ and $22 \mathrm{E} \%$ in the reference scenario. Partial - or full - replacement of meat and dairy with plant-based substitutes increased daily fibre intake among men and women, but the habitual median intake remained below the AI. Habitual $\mathrm{Na}$ intake decreased slightly, but only significantly among men in the 'no meat and dairy' scenario (-9\%).

\section{Micronutrients}

The observed median habitual $\mathrm{Ca}$ intake varied around $1128 \mathrm{mg} / \mathrm{d}$ for men and $989 \mathrm{mg} / \mathrm{d}$ for women depending on age (Table 5). In the 'no meat and dairy' scenario, median Ca intake decreased significantly by $25 \%$ to $839 \mathrm{mg} / \mathrm{d}$ for men and $737 \mathrm{mg} / \mathrm{d}$ for women. The median $\mathrm{Ca}$ intake in the replacement scenarios was below the AI for most age-gender categories. In the reference scenario, daily habitual Fe intake was $10 \cdot 3-12 \cdot 8 \mathrm{mg} / \mathrm{d}$ depending on age and gender. In the 'less meat and dairy' and 'no meat and dairy' scenarios, habitual Fe intake increased by $7 \%$ and $21 \%$ for men and $6 \%$ and $19 \%$ for women, respectively. Among women of fertile age, this higher Fe intake decreased the proportion of women with intakes below the corresponding EAR. The mean habitual $\mathrm{Zn}$ intake in the reference scenario ranged from 11.0 to $13.3 \mathrm{mg} / \mathrm{d}$. $\mathrm{Zn}$ intake already decreased significantly by $10-12 \%$ in the 'less meat and dairy' scenario. However, the risk of inadequate intakes remained low ( $1 \%$ below the EAR). Habitual $\mathrm{Zn}$ intake in the 'no meat and dairy' scenario decreased by $29 \%$ for women and $45 \%$ for men, leading to higher proportions of the population with intake below the corresponding EAR (21\% for women and 24\% for men). No adults exceeded the UL of $2500 \mathrm{mg} / \mathrm{d}$.

Mean habitual intake of total vitamin A was approximately $995 \mu \mathrm{g}$ RAE (retinol activity equivalents)/d for men and $897 \mu \mathrm{g} \mathrm{RAE} / \mathrm{d}$ for women in the reference scenario. Vitamin A intake decreased significantly in the 'no meat and dairy' scenario, leading to $64 \%$ of men and $58 \%$ of women having an intake below the corresponding EAR. The risk of excessive vitamin A intake remained low: 2-5\% for women aged 51-69 years and 0\% for other age-gender categories (data not shown). Daily habitual intake of thiamin did not change significantly over the three scenarios for adults aged 19-50 years. However, in the 'no meat and dairy' scenario, 28-31\% of women aged 19-50 years had an intake below the EAR, whereas the percentage in men was $10-12 \%$ below the EAR. Daily intake of riboflavin did not change significantly from the reference and risk of inadequate intake remained relatively low in both replacement scenarios, with a maximum of $10 \%$ below the EAR for men in the 'no meat and dairy' scenario. Mean habitual vitamin $\mathrm{B}_{12}$ intake decreased significantly for men (-41\%), but not significantly for women $(-27 \%)$, in the 'no meat and dairy' scenario compared with the reference. Especially for women, the confidence bounds around the mean habitual vitamin $\mathrm{B}_{12}$ intake were large. For both genders, the proportion of adults with an intake below the corresponding EAR increased from $0-1 \%$ in the reference scenario to $23-29 \%$ in the 'no meat and dairy' scenario. The median habitual intake of vitamin D increased significantly by $32-34 \%$ in the 'no meat and dairy' scenario compared with the reference, but remained below the AI of $10 \mu \mathrm{g} / \mathrm{d}$ for all age-gender groups. There was no risk of excessive vitamin $\mathrm{D}$ intake in any scenario (0\% above the UL).

\section{Discussion}

The present study evaluated the nutrient intakes of adults when meat and dairy products were partially or fully replaced by plant-based alternatives. The 'less meat and dairy' scenario (30\% replacement) did not substantially alter percentages below the EAR over the range of nutrients in all age-gender groups compared with the reference, while lowering GHG emissions and land use of daily diets by $\sim 14 \%$. The 'no meat and dairy' scenario (100\% replacement) was nutritionally inadequate with respect to vitamin $\mathrm{A}$, thiamin, vitamin $\mathrm{B}_{12}$ and $\mathrm{Zn}$ intakes, despite reducing environmental impacts by $>40 \%$. When replacing meat and dairy foods with plant-based alternatives in these scenarios, intakes of SFA, fibre, $\mathrm{Na}$ and vitamin $\mathrm{D}$ were more in line with dietary recommendations.

\section{Nutritional adequacy of dietary scenarios}

In the present study, nutritional adequacy was assessed by comparing the population's habitual nutrient intakes with age- and gender-specific DRI. No additional biomarkers were measured. This study therefore has more of a signalling function to assess the risks and benefits on a population level when shifting towards more plant-based diets. It should be noted that the EAR cut-point method is valid for all nutrients in the study except for Fe, where the true prevalence of inadequate intake may be underestimated for women of fertile age due to different requirements ${ }^{(24)}$.

Replacing all meat and dairy in the diet with plant-based alternatives increased the risk of inadequate micronutrient intakes for $\mathrm{Zn}$, thiamin and vitamin $\mathrm{B}_{12}$, with up to $10-31 \%$ of adults having intakes below the EAR. For vitamin A, about $60 \%$ of the population had intakes below the EAR (16-19\% were below the EAR in the reference scenario). For $\mathrm{Ca}$, the median intakes were below the AI in both replacement scenarios. These results are in line with previous dietary simulations ${ }^{(17,39)}$. Even though protein intake was reduced by $\sim 20 \%$ in the 'no meat and dairy' scenario, protein intakes were still adequate on a population level. Protein requirements may be $20 \%$ higher among vegetarians due to the lower protein quality of plant sources as compared with animal sources ${ }^{(28)}$. Although not studied, we expect that the provision of essential amino acids is sufficient due to the variety of plant-based proteins in the 


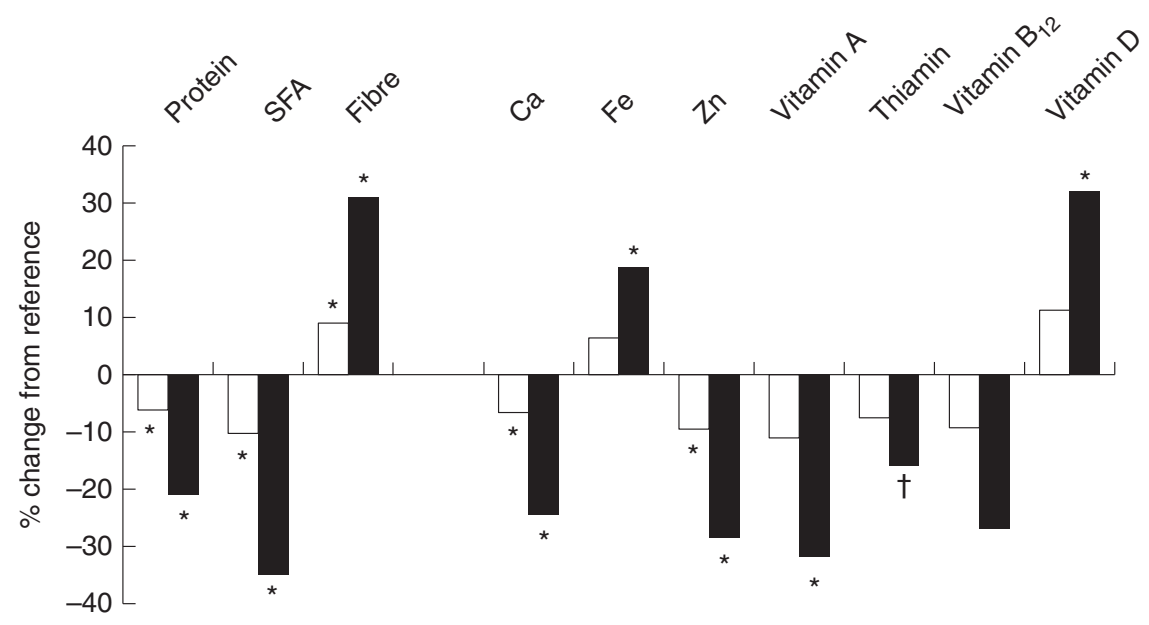

Fig. 1 Percentage change in nutrient intakes for the 'less meat and dairy' $(\square)$ and 'no meat and dairy' ( $\square$ ) scenarios compared with the reference scenario in Dutch women aged 19-69 years $(n$ 1047). The percentage change in nutrient intakes for men is comparable. *Significantly different from the reference scenario based on the $95 \% \mathrm{Cl}$ around the habitual intake; †significant only for the age group 51-69 years

replacement scenarios and the high levels of daily protein intake.

Shifting to diets with fewer animal products and more plant-based foods is in accordance with advice from various health councils ${ }^{(40,41)}$ and could in our scenarios reduce intakes of SFA and $\mathrm{Na}$, while increasing fibre and vitamin D intakes. Diets low in SFA and high in fibre are, in the long term, associated with a reduced risk of CVD, cancer and obesity ${ }^{(42-44)}$. Particularly the 'no meat and dairy' scenario could reduce SFA intake by about $35 \%$ and increase fibre intake by $>30 \%$. Na intake could not, however, be compared directly with the dietary guidelines because salt added to foods during preparation or at the table was not included ${ }^{(20)}$. Assuming that the amounts of added salt were similar in every scenario, the Na intakes in the 'no meat and dairy' scenario were significantly lower compared with the reference scenario. Although reduced, the mean $\mathrm{Na}$ intakes were still above the recommendation of $<2 \mathrm{~g} / \mathrm{d}^{(45)}$ in the replacement scenarios. The increase in vitamin $\mathrm{D}$ intakes in the replacement scenarios is likely due to the fortification of dairy replacements (Table 3).

The risk of inadequate intakes of vitamin $\mathrm{A}$, thiamin, vitamin $\mathrm{B}_{12}$, $\mathrm{Zn}$ and probably $\mathrm{Ca}$ warrants attention. These micronutrients can also be derived from plant sources (albeit in smaller amounts/lower bioavailability) except for vitamin $\mathrm{B}_{12}$. Vitamin $\mathrm{B}_{12}$, in its natural form, is present mainly in foods of animal origin ${ }^{(32)}$. Some plant foods such as a few types of edible algae and mushrooms are known to contain vitamin $\mathrm{B}_{12}$, but their biological activity and effect on $\mathrm{B}_{12}$ status in man are inconclusive ${ }^{(46)}$. When no animal foods are consumed, the intake depends largely on fortified foods and/or dietary supplements. The percentage reduction in vitamin $\mathrm{B}_{12}$ intake was larger in men's diet $(-41 \%)$ than in women's diet $(-27 \%)$ in the 'no meat and dairy' scenario, likely due to the higher meat consumption among men in the reference scenario
(185 g/d for men and $119 \mathrm{~g} / \mathrm{d}$ for women; DNFCS 20072010). Based on serum vitamin $B_{12}$ levels, individuals who follow a vegan diet and do not take vitamin $\mathrm{B}_{12}$ supplements, or eat foods enriched with this vitamin, were more prone to vitamin $\mathrm{B}_{12}$ deficiency than those adhering to other vegetarian diets ${ }^{(15)}$. Vitamin A intake in Western countries mostly results from consumption of milk, butter, cheese, eggs, liver and fatty fish, but it can also be synthesised from plant foods (in the form of carotenoids) naturally present in green leafy vegetables (as well as carrots), and yellow and orange fruits. Vitamin A is also present in enriched margarines in the Netherlands ${ }^{(31)}$. The EAR for vitamin A is based on adequate liver stores and it is yet unknown whether intakes below this EAR will result in health problems ${ }^{(31)}$. Thiamin can be obtained from meat and dairy products, but also from cereal products ${ }^{(12)}$. Ca intake decreased by $25 \%$ in the 'no meat and dairy' scenario, but only a qualitative assessment could be made by comparison to an AI. Large Ca sources are milk and dairy products that account for $58 \%$ of $\mathrm{Ca}$ intake in the Dutch population, while cereal products (8\%) and vegetables $(5 \%)$ have a small contribution ${ }^{(16)}$. In the less meat and dairy' scenario, $\mathrm{Zn}$ intake remained adequate; however, the 'no meat and dairy' scenario showed that $21-24 \%$ of the population would have intakes below the EAR. Sources of $\mathrm{Zn}$ are meat and milk products, but also wholegrain cereals ${ }^{(12)}$; however, bioavailability of the latter may be reduced considerably by phytic acid ${ }^{(14)}$.

\section{Bioavailability of micronutrients}

When eating a largely plant-based diet, a potential concern is the lower bioavailability of Fe and Zn. Absorption may be reduced when increasing phytate-containing pulses and whole grains in the diet ${ }^{(14,47)}$. Fe requirements for vegetarians may be up to $80 \%$ higher than for people who eat a mixed Western diet ${ }^{(48)}$. Although vegetarians have 
Table 4 Habitual intakes of energy, macronutrients and sodium, and the evaluation in different meat and dairy replacement scenarios, among Dutch adults (1055 men and 1047 women) aged 19-69 years, weighted for sociodemographic factors, season and day of the week. Results are presented as point estimates with their $95 \% \mathrm{Cl}$

\begin{tabular}{|c|c|c|c|c|c|c|c|c|c|c|c|c|c|}
\hline \multirow[b]{4}{*}{ Nutrient/Gender } & \multirow[b]{4}{*}{ Recommendation } & \multicolumn{4}{|c|}{ Reference scenario } & \multicolumn{4}{|c|}{ 'Less meat and dairy' scenario } & \multicolumn{4}{|c|}{ 'No meat and dairy' scenario } \\
\hline & & \multicolumn{4}{|c|}{ No replacement } & \multicolumn{4}{|c|}{$30 \%$ replacement $^{*}$} & \multicolumn{4}{|c|}{$100 \%$ replacement $^{*}$} \\
\hline & & \multirow[b]{2}{*}{ Mean } & \multirow[b]{2}{*}{$95 \% \mathrm{Cl}$} & \multicolumn{2}{|c|}{ Evaluation } & \multirow[b]{2}{*}{ Mean } & \multirow[b]{2}{*}{$95 \% \mathrm{Cl}$} & \multicolumn{2}{|c|}{ Evaluation } & \multirow[b]{2}{*}{ Mean } & \multirow[b]{2}{*}{$95 \% \mathrm{Cl}$} & \multicolumn{2}{|c|}{ Evaluation } \\
\hline & & & & Estimate & $95 \% \mathrm{Cl}$ & & & Estimate & $95 \% \mathrm{Cl}$ & & & Estimate & $95 \% \mathrm{Cl}$ \\
\hline \multicolumn{14}{|l|}{ Energy $(\mathrm{MJ} / \mathrm{d}) \dagger, \ddagger$} \\
\hline Men & $11.0-12.9(\mathrm{EAR})$ & $11 \cdot 0^{\mathrm{a}}$ & $10 \cdot 8,11 \cdot 9$ & & & $10 \cdot 9^{a}$ & $10 \cdot 8,11 \cdot 8$ & & & $10 \cdot 8^{a}$ & $10 \cdot 6,11.6$ & & \\
\hline Women & 9.0-10.2 (EAR) & $8 \cdot 4^{a}$ & $8 \cdot 1,8.5$ & & & $8 \cdot 4^{a}$ & $8 \cdot 1,8.6$ & & & $8 \cdot 3^{a}$ & $8.0,8.4$ & & \\
\hline Protein $(\mathrm{g}) \ddagger$ & & & & \multicolumn{2}{|c|}{$\%<\mathrm{EAR}$} & & & \multicolumn{2}{|c|}{$\%<$ EAR } & & & \multicolumn{2}{|c|}{$\%<$ EAR } \\
\hline Men & 45-47 (EAR) & $98^{\mathrm{a}}$ & 96,106 & 0 & 0,0 & $92^{\mathrm{a}}$ & 90,100 & 0 & 0,0 & $77^{\mathrm{b}}$ & 75,83 & 1 & 0,2 \\
\hline Women & 39-40 (EAR) & $76^{\mathrm{a}}$ & 74,78 & 0 & 0,1 & $71^{\mathrm{b}}$ & 69,73 & 0 & 0,1 & $60^{c}$ & 58,61 & 3 & 2,5 \\
\hline SFA (E\%)‡ & & & \multicolumn{3}{|c|}{$\%>$ UL } & & & \multicolumn{2}{|c|}{$\%>$ UL } & & & \multicolumn{2}{|c|}{$\%>U L$} \\
\hline Men & 10 (UL) & $14^{\mathrm{a}}$ & 13,15 & 97 & 92,100 & $12^{\mathrm{a}}$ & 11,13 & 89 & 77,95 & $9^{b}$ & 8,9 & 19 & 8,24 \\
\hline Women & 10 (UL) & $13^{\mathrm{a}}$ & 13,14 & 91 & 88,95 & $12^{\mathrm{b}}$ & 11,12 & 79 & 75,86 & $9^{c}$ & 8,9 & 17 & 12,24 \\
\hline \multicolumn{14}{|c|}{ Mono- and disaccharides (E\%) } \\
\hline Men & - & $20^{\mathrm{a}}$ & 19,20 & & & $21^{\mathrm{a}}$ & 20,21 & & & $23^{\mathrm{b}}$ & 22,24 & & \\
\hline Women & - & $22^{\mathrm{a}}$ & 21,23 & \multirow{2}{*}{\multicolumn{2}{|c|}{ Adequacy }} & $23^{a, b}$ & 22,24 & & & $26^{\mathrm{b}}$ & 24,26 & \multirow{3}{*}{\multicolumn{2}{|c|}{$\begin{array}{c}\text { Adequacy } \\
\text { ns }\end{array}$}} \\
\hline Fibre (g/MJ)§ & & & & & & & & Adeq & lacy & & & & \\
\hline Men & $3.4(\mathrm{Al})$ & $2 \cdot 1 \Phi^{\mathrm{a}}$ & $2 \cdot 1,2 \cdot 2$ & & & $2.4 \prod^{b}$ & $2 \cdot 3,2 \cdot 4$ & $\mathrm{n}$ & & $2 \cdot 9^{\mathrm{c}}$ & $2 \cdot 9,3 \cdot 0$ & & \\
\hline Women & 3.4 (Al) & $2 \cdot 3 \mathbb{1}^{\mathrm{a}}$ & $2 \cdot 3,2 \cdot 4$ & & & $2 \cdot 6 \|^{b}$ & $2 \cdot 5,2.6$ & $\mathrm{n}$ & & $3 \cdot 1^{c}$ & $3 \cdot 1,3 \cdot 2$ & $n$ & \\
\hline \multicolumn{14}{|l|}{$\mathrm{Na}(\mathrm{g} / \mathrm{d}) \|$} \\
\hline Men & - & $3 \cdot 1^{\mathrm{a}}$ & $3 \cdot 1,3 \cdot 3$ & & & $3.1^{\mathrm{a}}$ & $3 \cdot 1,3 \cdot 2$ & & & $2 \cdot 9^{\mathrm{b}}$ & $2 \cdot 9,3 \cdot 0$ & & \\
\hline Women & - & $2 \cdot 4^{\mathrm{a}}$ & $2.4,2.5$ & & & $2 \cdot 3^{a, b}$ & $2 \cdot 3,2 \cdot 4$ & & & $2 \cdot 2^{b}$ & $2 \cdot 2,2 \cdot 3$ & & \\
\hline
\end{tabular}

E\%, percentage of daily energy intake; EAR, Estimated Average Requirement; UL, Tolerable Upper Intake Level; Al, Adequate Intake; ns, median intake is below corresponding Al and therefore no statement about the adequacy can be made.

a,b,c Mean/median values between scenarios with unlike superscript letters were significantly different (based on the $95 \% \mathrm{Cl}$ around the point estimate as estimated using 200 bootstrap samples).

*Replacement of meat and cheese as sandwich filling and snack, meat for dinner and dairy drinks and desserts by plant-derived substitutes.

†Average energy intake varies with age and gender and is based on a moderately active lifestyle (physical activity level $=1.7$ ). Due to the high correlation between energy intakes and requirements, no statement about

†EAR for energy and protein and UL for SFA from the Health Council of the Netherlands $(2001)^{(28)}$

Al for fibre from the Health Council of the Netherlands $(2006)^{(29)}$

$\mathrm{Na}$ intake is based on prepat

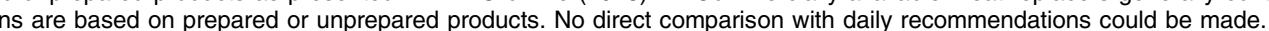

IMedian point estimate. 


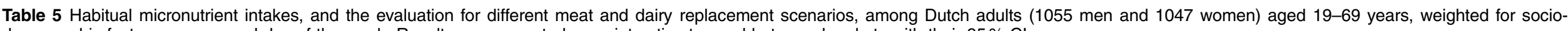
demographic factors, season and day of the week. Results are presented as point estimates and between brackets with their $95 \% \mathrm{Cl}$

\begin{tabular}{|c|c|c|c|c|c|c|c|c|c|c|c|c|c|c|c|c|c|c|c|c|c|c|}
\hline \multirow[b]{4}{*}{ Nutrient/gender } & & & & & \multicolumn{6}{|c|}{ Reference scenario } & \multicolumn{6}{|c|}{ 'Less meat and dairy' scenario } & \multicolumn{6}{|c|}{ 'No meat and dairy' scenario } \\
\hline & & & & & \multicolumn{6}{|c|}{ No replacement } & \multicolumn{6}{|c|}{$30 \%$ replacement ${ }^{*}$} & \multicolumn{6}{|c|}{$100 \%$ replacement ${ }^{*}$} \\
\hline & & & & & & & & Evalu & ration & & & & & Evalu & ration & & & & & Evalu & uation & \\
\hline & $\begin{array}{l}\text { Age group } \\
\text { (years) }\end{array}$ & \multicolumn{3}{|c|}{ Recommendation } & Mean & $95 \% \mathrm{Cl}$ & Estimate & $95 \% \mathrm{Cl}$ & Estimate & $95 \% \mathrm{Cl}$ & Mean & $95 \% \mathrm{Cl}$ & Estimate & $95 \% \mathrm{Cl}$ & Estimate & $95 \% \mathrm{Cl}$ & Mean & $95 \% \mathrm{Cl}$ & Estimate & $95 \% \mathrm{Cl}$ & Estimate & $95 \% \mathrm{Cl}$ \\
\hline $\mathrm{Ca}(\mathrm{mg} / \mathrm{d})$ & & & AI§ & UL§ & & & \multicolumn{2}{|c|}{ Adequacy } & \multicolumn{2}{|c|}{$\%>$ UL } & & & \multicolumn{2}{|c|}{ Adequacy } & \multicolumn{2}{|c|}{$\%>U L$} & & & \multicolumn{2}{|c|}{ Adequacy } & \multicolumn{2}{|c|}{$\%>U L$} \\
\hline Men & $19-69$ & & $1000 / 1100$ & 2500 & $1128 \mathbb{q}^{\mathrm{a}}$ & 1101,1160 & \multicolumn{2}{|c|}{ ns } & 0 & 0,0 & $1044 \prod^{b}$ & 1010,1069 & \multirow{2}{*}{\multicolumn{2}{|c|}{$\begin{array}{l}\text { ns } \\
\text { ns }\end{array}$}} & 0 & 0,0 & $839 \rrbracket^{c}$ & 810,860 & \multirow{2}{*}{\multicolumn{2}{|c|}{$\begin{array}{l}\text { ns } \\
\text { ns }\end{array}$}} & 0 & 0,0 \\
\hline $\begin{array}{l}\text { Women } \\
\mathrm{Fe}(\mathrm{mg} / \mathrm{d}) \mathrm{t}\end{array}$ & $19-69$ & EABt & $1000 / 1100$ & 2500 & $989 \rrbracket^{a}$ & 964,1014 & \multicolumn{2}{|c|}{$\begin{array}{c}n s \\
\%<\text { EAR }\end{array}$} & 0 & 0,0 & $920 \prod^{b}$ & 897,947 & & & 0 & 0,0 & $7379^{c}$ & 719,763 & & & 0 & 0,0 \\
\hline $\begin{array}{l}\mathrm{Fe}(\mathrm{mg} / \mathrm{d}) \dagger \\
\text { Men }\end{array}$ & $19-69$ & $\begin{array}{l}\text { EARF } \\
7\end{array}$ & & & $12 \cdot 8^{\mathrm{a}}$ & $12 \cdot 5,13 \cdot 1$ & $\begin{array}{l}\%<t<-10 \\
1\end{array}$ & $\begin{array}{ll}E A R \\
1,3\end{array}$ & & & $13.7^{\mathrm{b}}$ & $13 \cdot 3,13 \cdot 9$ & $\begin{array}{l}\%<t<1 \\
1\end{array}$ & $\begin{array}{l}\text { EAR } \\
0,1\end{array}$ & & & $15 \cdot 4^{\mathrm{C}}$ & $15 \cdot 0,15 \cdot 7$ & $\begin{array}{l}\%<1 \\
0\end{array}$ & $\begin{array}{l}\text { EAR } \\
0,0\end{array}$ & & \\
\hline \multirow{3}{*}{$\begin{array}{l}\text { Men } \\
\text { Women }\end{array}$} & $19-30$ & 10 & & & $10 \cdot 3^{\mathrm{a}}$ & $9 \cdot 8,10 \cdot 8$ & 57 & 53,64 & & & $10 \cdot 7^{\mathrm{a}}$ & $10 \cdot 3,11 \cdot 2$ & 49 & 44,54 & & & $12 \cdot 5^{\mathrm{b}}$ & $11.9,12.9$ & 26 & 20,31 & & \\
\hline & $31-50$ & 10 & & & $11 \cdot 7^{\mathrm{a}}$ & $11 \cdot 3,12 \cdot 6$ & 40 & 34,44 & & & $12 \cdot 5^{\mathrm{a}}$ & $12 \cdot 0,13 \cdot 3$ & 30 & 22,33 & & & $14.0^{\mathrm{b}}$ & $13 \cdot 5,14 \cdot 9$ & 14 & 9,16 & & \\
\hline & $51-69$ & 6 & & & $12 \cdot 2^{\mathrm{a}}$ & $11 \cdot 6,12 \cdot 8$ & 0 & 0,1 & & & $13 \cdot 1^{\mathrm{a}}$ & $12 \cdot 3,13 \cdot 4$ & & 0,1 & & & $14 \cdot 2^{\mathrm{b}}$ & $13 \cdot 7,14 \cdot 9$ & & 0,0 & & \\
\hline $\mathrm{Zn}(\mathrm{mg} / \mathrm{d})$ & & EAR $\ddagger$ & & UL\| & & & $\%<\mathrm{E}$ & EAR & $\%>>$ & UL & & & $\%<1$ & EAR & $\%>$ & UL & & & $\%<1$ & EAR & & $>$ UL \\
\hline Men & $19-69$ & 6 & & 25 & $13 \cdot 3^{\mathrm{a}}$ & $12 \cdot 9,13 \cdot 6$ & 0 & 0,0 & 2 & 1,2 & $11.7^{\mathrm{b}}$ & $11 \cdot 3,11 \cdot 9$ & 1 & 0,1 & 1 & 0,2 & $7.9^{c}$ & $7 \cdot 6,8 \cdot 1$ & 24 & 20,27 & 0 & 0,1 \\
\hline Wome & $19-69$ & 5 & & 25 & $11 \cdot 0^{\mathrm{a}}$ & $10 \cdot 7$ & 0 & 0,1 & 1 & 0,1 & $10.0^{\mathrm{b}}$ & $9 \cdot 6,10 \cdot 2$ & 1 & 0,2 & 1 & 0,1 & $7 \cdot 3^{\mathrm{c}}$ & $7.0,7.5$ & 21 & 18,23 & 0 & 0,1 \\
\hline Vitamin A ( $\mu \mathrm{g} \mathrm{RAE} / \mathrm{d})$ & & EAR§ & & & & & $\%<\mathrm{E}$ & EAR & & & & & $\%<1$ & EAR & & & & & $\%<1<1$ & EAR & & \\
\hline Men & $19-69$ & $620 / 610$ & & & $995^{\mathrm{a}}$ & 948,1068 & 16 & 11,20 & & & $883^{a}$ & 844,961 & 25 & 20,30 & & & $596^{\mathrm{b}}$ & 574,632 & 64 & 60,67 & & \\
\hline Wome & $19-69$ & 530 & & & $897^{\mathrm{a}}$ & 844,968 & 19 & 14,23 & & & $798^{\mathrm{a}}$ & 760,850 & & 22,31 & & & $612^{\mathrm{b}}$ & 573,657 & & 54,62 & & \\
\hline Thiamin $(\mathrm{mg} / \mathrm{d})$ & & EAR§ & Al§ & & & & $\%<\mathrm{E}$ & EAR & Adeq & quacy & & & $\%<1<$ & EAR & Adec & juacy & & & $\%<1$ & EAR & Adeq & quacy \\
\hline Men & $19-30$ & 0.8 & & & $1.64^{\mathrm{a}}$ & 1. & 1 & 0,3 & & & 1.5 & 1. & 3 & 1,6 & & & 1.3 & $1 \cdot 1$ & 10 & 8,18 & & \\
\hline & $31-50$ & 0.8 & & & $1.88^{\mathrm{a}}$ & $1.55,2.75$ & 2 & 0,4 & & & $1.85^{\mathrm{a}}$ & $1.46,2.65$ & 4 & 2,7 & & & $1.63^{\mathrm{a}}$ & $1.26,2.42$ & 12 & 7,16 & & \\
\hline & $51-69$ & & $1 \cdot 1$ & & $1.36 \|^{a}$ & $1.29,1.42$ & & & $\mathrm{a}$ & ad & $1.26 \pi^{a}$ & $1 \cdot 19,1.31$ & & & a & d & $1.06 \boldsymbol{\eta}^{\mathrm{b}}$ & $1.01,1 \cdot 10$ & & & & ns \\
\hline Women & $19-30$ & 0.8 & & & $1.98^{a}$ & $1 \cdot 37,2 \cdot 34$ & 14 & 8,19 & & & $1.59^{\mathrm{a}}$ & $1.31,2.40$ & 17 & 11,23 & & & $1.63^{a}$ & $1 \cdot 17,2 \cdot 15$ & 31 & 24,38 & & \\
\hline & $31-50$ & 0.8 & & & $2.08^{\mathrm{a}}$ & $1.54,2.65$ & 12 & 7,14 & & & $2 \cdot 07^{\mathrm{a}}$ & $1.46,2.58$ & 15 & 10,19 & & & $1.84^{\mathrm{a}}$ & $1.33,2.41$ & 28 & 21,32 & & \\
\hline & $51-69$ & & 1.1 & & $1 \cdot 27 \boldsymbol{\Psi}^{\mathrm{a}}$ & 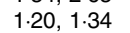 & & & $\mathrm{a}$ & d & $1.19 q^{a}$ & $1 \cdot 13,1.26$ & & & $\mathrm{a}$ & d & $1.04 \boldsymbol{\Phi}^{b}$ & $0.97,1 \cdot 10$ & & & & ns \\
\hline Riboflavin (mg/d) & & EAR§ & & & & & $\%<\mathrm{E}$ & EAR & & & & & $\%<1<1-1$ & EAR & & & & & $\%<1<1<-1$ & EAR & & \\
\hline Men & $19-69$ & 1.1 & & & $2 \cdot 23^{\mathrm{a}}$ & $2.05,2.41$ & 7 & 4,10 & & & $2 \cdot 13^{\mathrm{a}}$ & $2 \cdot 02,2 \cdot 40$ & 8 & 5,10 & & & $2 \cdot 25^{\mathrm{a}}$ & $2 \cdot 00,2 \cdot 40$ & 10 & 6,12 & & \\
\hline Women & $19-69$ & 0.8 & & & $2 \cdot 60^{\mathrm{a}}$ & $2.02,3.03$ & 3 & 2,5 & & & $2 \cdot 66^{\mathrm{a}}$ & $2.03,3 \cdot 18$ & & 1,5 & & & $2 \cdot 40^{\mathrm{a}}$ & $2.00,3.08$ & & 3,7 & & \\
\hline Vitamin $B_{12}(\mu \mathrm{g} / \mathrm{d})$ & & EAR§ & & & & & $\%<E$ & EAR & & & & & $\%<1$ & EAR & & & & & $\%<1<1$ & EAR & & \\
\hline Men & $19-69$ & 2 & & & $5.83^{\mathrm{a}}$ & $5 \cdot 65,6 \cdot 27$ & 0 & 0,1 & & & $5 \cdot 07^{b}$ & 4.94 & 1 & 0,2 & & & $3.44^{\mathrm{c}}$ & $3.21,3.77$ & 23 & 18,27 & & \\
\hline Women & $19-69$ & 2 & & & $6.02^{\mathrm{a}}$ & $5 \cdot 27,6.84$ & 1 & 0,3 & & & $5 \cdot 46^{\mathrm{a}}$ & $4 \cdot 77,6 \cdot 31$ & & 2,6 & & & $4 \cdot 39^{\mathrm{a}}$ & $3.58,5.45$ & 29 & 24,33 & & \\
\hline Vitamin D $(\mu \mathrm{g} / \mathrm{d})$ & & & Al§ & UL\| & & & Adequ & uacy & & UL & & & Adeq & dacy & $\%>>$ & UL & & & Adeq & uacy & & $>\mathrm{UL}$ \\
\hline Men & $19-69$ & & 10 & 100 & $4 \cdot 2 \rrbracket^{a}$ & 1.4 & ns & & 0 & 0,0 & $4 \cdot 6 \boldsymbol{\Phi}^{b}$ & $4 \cdot 5,4 \cdot 8$ & $\mathrm{n}$ & & 0 & 0,0 & $5 \cdot 79^{c}$ & $5.4,5.9$ & ns & & & 0,0 \\
\hline Women & $19-69$ & & 10 & 100 & $3.5 \pi^{a}$ & $3.3,3 \cdot 7$ & $\mathrm{~ns}$ & & 0 & 0,0 & $3.9 \|^{a}$ & $3 \cdot 7,4 \cdot 1$ & $n$ & & 0 & 0,0 & $4.8 \pi^{\mathrm{b}}$ & $4 \cdot 6,5 \cdot 0$ & ns & & 0 & 0,0 \\
\hline
\end{tabular}

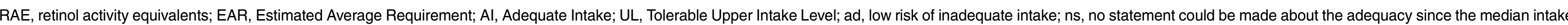

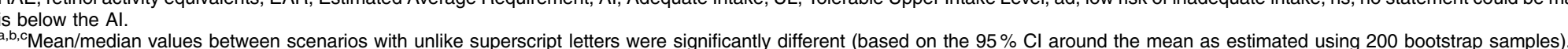

*Replacement of meat and cheese as sandwich filling and snack, meat for dinner and dairy drinks and desserts by plant-derived substitutes.

tFe intake was estimated without taking into account difference in bioavailability between animal and plant sources.

EAR for Fe and $\mathrm{Zn}$ from the Nordic Council of Ministers $(2014)^{(12)}$

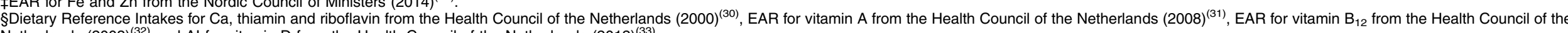

Al for vitamin D from the Health Council of the Netherlands $(2012)^{(33)}$.

$\mathrm{UL}$ for $\mathrm{Zn}$ from the European Food Safety Authority $(2006)^{(34)}$ and for vitamin D from the European Food Safety Authority $(2012)^{(35)}$

IMedian point estimate. 
lower Fe stores, no adverse health effects from decreased $\mathrm{Fe}$ and $\mathrm{Zn}$ absorption have been demonstrated with varied vegetarian diets in developed countries ${ }^{(14)}$. The increase in total $\mathrm{Fe}$ intake in our replacement scenarios is probably due to non-haem Fe in fortified meat replacers (Table 3). For vegetarian cereal-based diets, it is advised to increase $\mathrm{Zn}$ intake by $25-30 \%{ }^{(12)}$. Due to a reduced bioavailability of $\mathrm{Zn}$ and Fe, it may be necessary to adjust DRI when shifting towards more plant-based consumption patterns.

\section{Methodological considerations and limitations}

Inherent to the study design, the choice of substitutes and their corresponding composition remain crucial for the nutritional intake estimations made in the different scenarios. Plant-based alternatives were chosen from the point of view of reducing environmental impact as well as staying as close as possible to the current Dutch eating habits per consumption occasion. Most people in the Netherlands eat bread with sandwich fillings for breakfast and lunch, and a hot meal for dinner. From a taste perspective, replacing meat during dinner with dishes made with pulses, tofu or vegetarian meat replacements results in similar savoury taste. However, for the meat and cheese sandwich fillings, finding plant-based alternatives with a similar taste profile was more difficult. Two-thirds of the animal-based sandwich fillings were replaced with sweet fillings such as chocolate sprinkles and apple syrup and one-third by savoury sandwich fillings such as peanut butter. This choice affected sugar intake levels. Although foods with sugar have lower environmental impacts compared with meat and cheese, recent nutrition recommendations advise limiting free sugars below $10 \%$ of total energy intake ${ }^{(49)}$. An increase in mono- and disaccharide intakes (used as a proxy for free sugars) of 3-4 E\% as in the 'no meat and dairy' scenario can be prevented by choosing more recently available plant-based fillings (and snacks) with low sugar content such as hummus.

Another possible limitation is that replacements were made based on equal food weights, which may be realistic for meat replacements during dinner and replacement of sandwich fillings but not for replacement with popcorn because of differences in food volumes. Although affordability of the diets was not assessed in our study, others observed that a higher adherence to a healthy diet was associated with higher dietary costs ${ }^{(50,51)}$.

\section{Diet optimisation}

Our 'no meat and dairy' scenario was not optimal for certain micronutrient intakes. Recent diet optimisation modelling studies showed that GHG emission reductions of $\leq 30 \%{ }^{(52)}$ or $\leq 40 \%{ }^{(53)}$ were compatible with nutrient recommendations without major changes to the diet. These studies suggest that relatively large reductions can be achieved without completely omitting meat and dairy, while remaining adequate, by for example reducing animal products, shifting towards types of meat product with lower emissions (e.g. chicken and certain types of fish), increasing fruit, vegetables and cereal consumption, and reducing snacks ${ }^{(52,53)}$. When implementing more plant-based diets, attention to certain foods may help to cover micronutrient intakes. Yellow and orange fruits, green leafy vegetables, legumes, nuts and seeds, wholegrain cereals and soya products in the diet can contribute to intakes of vitamin A (in the form of carotenoids), thiamin, $\mathrm{Ca}$ and $\mathrm{Zn}^{(54-56)}$. Moreover, fortified foods and dietary supplements can be helpful in meeting recommendations for vitamin $\mathrm{B}_{12}{ }^{(15)}$. Variation in meat replacements is essential due to varying nutrient contents; for example, pulses do not contain vitamin $\mathrm{B}_{12}$, but have lower $\mathrm{Na}$ content than commercial meat replacements. In addition, choosing sandwich fillings and snacks with low sugar contents should prevent an increase in free sugar intake. Overall, when replacing only $30 \%$ of animal products with plant-based foods there is no immediate need for concern about inadequate intakes and for food tailoring in this Dutch adult population, in line with previous studies ${ }^{(52,53)}$.

\section{Conclusions}

Diets with all meat and dairy replaced with plant-based foods lowered environmental impacts by $>40 \%$. Intakes of $\mathrm{Zn}$, thiamin, vitamins $\mathrm{A}$ and $\mathrm{B}_{12}$, and probably $\mathrm{Ca}$, were below recommendations in this scenario. Replacing 30\% was beneficial for SFA, Na, fibre and vitamin D intakes, neutral for other nutrients, while reducing environmental impacts by $14 \%$. From the $30 \%$ replacement scenario, it can be concluded that there is room to reduce meat and dairy intakes without compromising nutritional adequacy of the diet. This would benefit environmental sustainability.

\section{Acknowledgements}

Acknowledgements: The authors thank Arnold Dekkers for his assistance in the analysis of habitual nutrient intakes as well as colleagues of the Dutch National Food Consumption Survey team for collecting the data. Financial support: This work was funded by the Dutch Ministry of Economic Affairs. The Ministry of Economic Affairs had no role in the design, analysis or writing of this article. Conflict of interest: None. Authorship: E.H.M.T. and S.M.S. designed the research; S.M.S. conducted the research, analysed the data and wrote the draft paper. E.H.M.T., J.V.-K. and S.B. provided comments on the draft versions. E.H.M.T. had primary responsibility for final content. All authors read and approved the final manuscript. Ethics of buman subject participation: Not applicable.

\section{References}

1. McMichael AJ, Powles JW, Butler CD et al. (2007) Food, livestock production, energy, climate change, and health. Lancet 370, 1253-1263. 
2. Garnett T (2013) Food sustainability: problems, perspectives and solutions. Proc Nutr Soc 72, 29-39.

3. World Resources Institute (2005) Ecosystems and Human Well-Being: Health. Synthesis - A Report of the Millennium Ecosystem Assessment. Washington, DC: World Resources Institute.

4. Gerber PJ, Steinfeld H, Henderson B et al. (2013) Tackling Climate Change Through Livestock - A Global Assessment of Emissions and Mitigation Opportunities. Rome: FAO.

5. Millward DJ \& Garnett T (2010) Plenary Lecture 3: Food and the planet: nutritional dilemmas of greenhouse gas emission reductions through reduced intakes of meat and dairy foods. Proc Nutr Soc 69, 103-118.

6. European Commission (2015) 2030 framework for climate and energy policies. http://ec.europa.eu/clima/policies/ 2030/index_en.htm (accessed October 2015).

7. Hallström E, Carlsson-Kanyama A \& Börjesson P (2015) Environmental impact of dietary change: a systematic review. J Cleaner Prod 91, 1-11.

8. Biesbroek S, Bueno-de-Mesquita HB, Peeters $\mathrm{PH}$ et al. (2014) Reducing our environmental footprint and improving our health: greenhouse gas emission and land use of usual diet and mortality in EPIC-NL: a prospective cohort study. Environ Health 13, 27.

9. Scarborough P, Allender S, Clarke D et al. (2012) Modelling the health impact of environmentally sustainable dietary scenarios in the UK. Eur J Clin Nutr 66, 710-715.

10. Tilman D \& Clark M (2014) Global diets link environmental sustainability and human health. Nature 515, 518-522.

11. Vieux F, Soler LG, Touazi D et al. (2013) High nutritional quality is not associated with low greenhouse gas emissions in self-selected diets of French adults. Am J Clin Nutr 97, 569-583.

12. Nordic Council of Ministers (2014) Nordic Nutrition Recommendations 2012. Integrating Nutrition and Physical Activity. Copenhagen: Norden.

13. Health Council of the Netherlands (2011) Guidelines for a Healthy Diet: The Ecological Perspective. Contract no. 2011/08. The Hague: Heath Council of the Netherlands.

14. Hunt JR (2003) Bioavailability of iron, zinc, and other trace minerals from vegetarian diets. Am J Clin Nutr 78, 3 Suppl, 633S-639S.

15. Pawlak R, Lester SE \& Babatunde T (2014) The prevalence of cobalamin deficiency among vegetarians assessed by serum vitamin $\mathrm{B}_{12}$ : a review of literature. Eur J Clin Nutr $\mathbf{6 8}$, 541-548.

16. Van Rossum CTM, Fransen HP, Verkaik-Kloosterman J et al. (2011) Dutch National Food Consumption Survey 20072010. Diet of Children and Adults aged 7 to 69 years. Bilthoven: National Institute for Public Health and the Environment.

17. Temme EH, Bakker HM, Seves SM, Verkaik-Kloosterman J et al. (2015) How may a shift towards a more sustainable food consumption pattern affect nutrient intakes of Dutch children? Public Health Nutr 18, 2468-2478.

18. Dutch Food Composition Table (2011) NEVO-table 2011. The Hague: National Institute for Public Health and the Environment/Netherlands Nutrition Centre.

19. Tijhuis MJ, Ezendam J, Westenbrink S et al. (2011) Replacement of Meat and Dairy by More Sustainable Protein Sources in the Netherlands. Quality of the Diet. RIVM Brief Rapport no. 350123001. Bilthoven: National Institute for Public Health and the Environment.

20. Dutch Food Composition Table (2013) NEVO-online version 2013/4.0. Bilthoven: National Institute for Public Health and the Environment; available at http://nevo-online.rivm.nl/

21. Netherlands Nutrition Centre (2015) How do I eat a varied vegetarian meal? (in Dutch). http://www.voedingscentrum.nl/ $\mathrm{nl} /$ schijf-van-vijf/eet-gevarieerd/vegetarisch-eten.aspx (accessed September 2015).
22. Dekkers AL, Verkaik-Kloosterman J, van Rossum CT et al. (2014) SPADE, a new statistical program to estimate habitual dietary intake from multiple food sources and dietary supplements. J Nutr 144, 2083-2091.

23. Verkaik-Kloosterman J, Dodd KW, Dekkers AL et al. (2011) A three-part, mixed-effects model to estimate the habitual total vitamin $\mathrm{D}$ intake distribution from food and dietary supplements in Dutch young children. J Nutr $\mathbf{1 4 1}$, 2055-2063.

24. Carriquiry AL (1999) Assessing the prevalence of nutrient inadequacy. Public Health Nutr 2, 23-33.

25. Ocké M, Buurma-Rethans E, De Boer E et al. (2013) Diet of Community-Dwelling Older Adults: Dutch National Food Consumption Survey Older Adults 2010-2012. Bilthoven: National Institute for Public Health and the Environment.

26. Institute of Medicine (2000) Dietary Reference Intakes. Applications in Dietary Assessment. Washington, DC: National Academy Press.

27. Trumbo P, Yates AA, Schlicker S et al. (2001) Dietary reference intakes: vitamin $\mathrm{A}$, vitamin $\mathrm{K}$, arsenic, boron, chromium, copper, iodine, iron, manganese, molybdenum, nickel, silicon, vanadium, and zinc. J Am Diet Assoc 101, 294-301.

28. Health Council of the Netherlands (2001) Dietary Reference Intakes: Energy, Proteins, Fats, and Digestible Carbohydrates. Contract no. 2001/19. The Hague: Health Council of the Netherlands.

29. Health Council of the Netherlands (2006) Guideline for Dietary Fibre Intake. Contract no. 2006/03. The Hague: Health Council of the Netherlands.

30. Health Council of the Netherlands (2000) Dietary Reference Intakes: Calcium, Vitamin D, Thiamine, Riboflavin, Niacin, Pantothenic Acid, and Biotin. Contract no. 2000/ 12. The Hague: Health Council of the Netherlands.

31. Health Council of the Netherlands (2008) Towards an Adequate Intake of Vitamin A. The Hague: Health Council of the Netherlands.

32. Health Council of the Netherlands (2003) Dietary Reference Intakes: Vitamin $B_{6}$, Folic Acid and Vitamin $B_{12}$. The Hague: Health Council of the Netherlands.

33. Health Council of the Netherlands (2012) Evaluation of the Dietary Reference Values for Vitamin D. Contract no. 2012/15E. The Hague: Health Council of the Netherlands.

34. European Food Safety Authority, Committee on Food and Panel on Dietetic Products Nutrition and Allergies (2006) Tolerable Upper Intake Levels for Vitamins and Minerals. Parma: EFSA.

35. European Food Safety Authority (2012) Scientific opinion on the tolerable upper intake level of vitamin D. EFSA J 10, 2813-2858.

36. Blonk H, Ponsioen T, Kool A et al. (2011) The Agri-Footprint Method. Methodological LCA Framework, Assumptions and Applied Data. Gouda: Blonk Milieu Advies.

37. Netherlands Nutrition Centre (2015) Meat replacers (in Dutch). http://www.voedingscentrum.nl/encyclopedie/vlees vervangers.aspx (accessed September 2015).

38. Alpro (2014) Het assortiment. http://www.alpro.com/nl/ drinks-naturel (accessed February 2014).

39. Temme EH, van der Voet H, Thissen JT et al. (2013) Replacement of meat and dairy by plant-derived foods: estimated effects on land use, iron and SFA intakes in young Dutch adult females. Public Health Nutr 16, 1900-1907.

40. Swedish National Food Agency (2015) Find Your Way to Eat Greener, Not too Much and be Active. Uppsala: Livsmedelsverket.

41. Health Council of the Netherlands (2015) Guidelines for a Healthy Diet. The Hague: Health Council of the Netherlands.

42. Kromhout D, Menotti A, Kesteloot $\mathrm{H}$ et al. (2002) Prevention of coronary heart disease by diet and lifestyle: evidence 
from prospective cross-cultural, cohort, and intervention studies. Circulation 105, 893-898.

43. Geissler C \& Powers H (2005) Human Nutrition. London: Elsevier Churchill Livingstone.

44. Gingras D \& Beliveau R (2011) Colorectal cancer prevention through dietary and lifestyle modifications. Cancer Microenviron 4, 133-139.

45. World Health Organization (2012) Guideline: Sodium Intake for Adults and Children. Geneva: WHO.

46. Watanabe F, Yabuta Y, Tanioka Y et al. (2013) Biologically active vitamin $\mathrm{B}_{12}$ compounds in foods for preventing deficiency among vegetarians and elderly subjects. J Agric Food Chem 61, 6769-6775.

47. Hurrell R \& Egli I (2010) Iron bioavailability and dietary reference values. Am J Clin Nutr 91, issue 5, 1461S-1467S.

48. Institute of Medicine (2001) Dietary Reference Intakes for Vitamin A, Vitamin K, Arsenic, Boron, Chromium, Copper, Iodine, Iron, Manganese, Molybdenum, Nickel, Silicon, Vanadium, and Zinc. Washington, DC: The National Academies Press.

49. World Health Organization (2015) Guideline: Sugars Intake for Adults and Children. Geneva: WHO.

50. Monsivais P, Scarborough P, Lloyd T et al. (2015) Greater accordance with the Dietary Approaches to Stop Hypertension dietary pattern is associated with lower diet-related greenhouse gas production but higher dietary costs in the United Kingdom. Am J Clin Nutr 102, 138-145.

51. Darmon N \& Drewnowski A (2015) Contribution of food prices and diet cost to socioeconomic disparities in diet quality and health: a systematic review and analysis. Nutr Rev 73, 643-660.

52. Perignon M, Masset G, Ferrari G et al. (2016) How low can dietary greenhouse gas emissions be reduced without impairing nutritional adequacy, affordability and acceptability of the diet? A modelling study to guide sustainable food choices. Public Health Nutr 19, 2662-2674.

53. Green R, Milner J, Dangour AD et al. (2015) The potential to reduce greenhouse gas emissions in the UK through healthy and realistic dietary change. Climatic Change 129, 253-265.

54. Saunders AV, Craig WJ \& Baines SK (2013) Zinc and vegetarian diets. Med J Aust 199, 4 Suppl., S17-S21.

55. Sette S, D'Addezio L, Piccinelli R et al. (2017) Intakes of whole grain in an Italian sample of children, adolescents and adults. Eur J Nutr 56, 521-533.

56. Beltran-de-Miguel B, Estevez-Santiago R \& OlmedillaAlonso B (2015) Assessment of dietary vitamin A intake (retinol, $\alpha$-carotene, $\beta$-carotene, $\beta$-cryptoxanthin) and its sources in the National Survey of Dietary Intake in Spain (2009-2010). Int J Food Sci Nutr 66, 706-712. 